\title{
COMPARISON OF ESOPHAGEAL MOTILITY IMPAIRMENT CAUSED BY CHAGAS' DISEASE IN TWO AGE GROUPS
}

\author{
Roberto Oliveira DANTAS and Lilian Rose Otoboni APRILE
}

\begin{abstract}
Background - Chagas' disease and the aging process cause loss of neurons of the esophageal myenteric plexus. Aim - To evaluate the esophageal motility impairment caused by Chagas' disease in two age groups. Our hypothesis was that the aging process may cause further esophageal motility impairment in patients with Chagas' disease. Methods - We studied the esophageal motility of 30 patients with Chagas' disease and dysphagia, with esophageal retention of barium sulfate and an esophageal diameter within the normal range. Fifteen were 34 to 59 years old (younger group, median 51 years) and 15 were 61 to 77 years old (older group, median 66 years). As a control group we studied 15 subjects aged 33 to 58 years (median 42 years) and 7 subjects aged 61 to 73 years (median 66 years). The esophageal contractions were measured by the manometric method with continuous perfusion after five swallows of a $5 \mathrm{~mL}$ bolus of water at 2, 7, 12 and $17 \mathrm{~cm}$ below the upper esophageal sphincter. Results - Patients with Chagas' disease had lower amplitude of contractions and fewer peristaltic, more simultaneous, and more non-conducted contractions than controls. Older patients with Chagas' disease had lower amplitude of contractions in the distal esophagus (mean \pm SE: $30.8 \pm 4.3 \mathrm{~mm} \mathrm{Hg}$ ) than younger patients $(51.9 \pm$ $8.6 \mathrm{~mm} \mathrm{Hg}$ ). From 12 to $17 \mathrm{~cm}$, older patients had more non-conducted (41\%) and fewer peristaltic (8\%) contractions than younger patients (non-conducted: $16 \%$, peristaltic: $21 \%$ ). Conclusion - Older patients with Chagas' disease with clinical and radiological examinations similar to those of younger patients had motility alterations suggesting that the aging process may cause further deterioration of esophageal motility.
\end{abstract}

HEADINGS - Esophagus. Chagas' disease. Aging. Achalasia. Esophageal motility.

\section{INTRODUCTION}

Chagas' disease is the consequence of infection by the flagellate protozoan Trypanosoma cruzi that causes mainly alterations in the esophagus, colon and heart ${ }^{(15,22)}$. There is degeneration and reduction of the neurons of the myenteric plexus $^{(15,16,22)}$ causing esophageal motility abnormalities similar to those of idiopathic achalasia, absent or partial lower esophageal sphincter relaxation and loss of peristaltic contractions in the esophageal body ${ }^{(5,22)}$. Most patients do not have these advanced manifestations of the disease, but even patients without dysphagia and with a normal radiologic esophageal examination may have some motility alterations ${ }^{(1,4)}$.

During the aging process there is a loss in the number of neurons in the gut myenteric plexus ${ }^{(16,19,27)}$. Intrinsic sensory neurons in the submucosal plexus undergo neurodegeneration earlier and to a greater extent than do other classes of enteric neurons $^{(27)}$. A significant loss of intrinsic neurons at an advanced age may lead to diminished motor output ${ }^{(27)}$.
Chagas' disease is transmitted more frequently during childhood $^{(16)}$. In most patients with esophageal manifestations of the disease the clinical, radiologic and manometric features remain unchanged for years ${ }^{(20)}$. It is possible that with the aging process the esophageal motility alterations of patients with non-advanced disease become more intense.

The objective of this study was to evaluate the esophageal motility impairment caused by Chagas' disease in two age groups. Our hypothesis was that older patients with non-advanced esophageal motility impairment caused by Chagas' disease have more intense motility alterations than younger patients.

\section{MATERIAL AND METHODS}

We studied 30 patients with dysphagia for solids and liquids, no regurgitation, esophageal radiologic examination with barium retention, slow transit, esophageal diameter less than $4 \mathrm{~cm}$, and a positive serologic test for Chagas'

Department of Internal Medicine, University of São Paulo School of Medicine of Ribeirão Preto, Ribeirão Preto, SP, Brazil.

Address for correspondence: Dr. Roberto Oliveira Dantas - Departamento de Clínica Médica, Faculdade de Medicina de Ribeirão Preto - USP - 14049-900 Ribeirão Preto, SP, Brazil. E-mail: rodantas@fmrp.usp.br 
disease. All had an epidemiologic history of having lived in endemic areas of the disease during some time in childhood. Endoscopic examination did not detect alterations in the esophageal mucosa. The patients (13 men and 17 women) were divided into a younger group, aged 34 to 59 years, median 51 years (mean \pm SD: $50 \pm 8$ years, $n=15$ ), with a duration of dysphagia of 1 to 40 years, median 5 years, and an older group aged 61 to 77 years, median 66 years (mean: $67 \pm 5$ years, $n=15$ ), with a duration of dysphagia of 1 to 60 years, median 10 years. They had not received previous treatment by pneumatic dilatation or esophagomyotomy and were living with mild dysphagia, eating slowly soft food, and sometimes drinking water during meals. The intensity of dysphagia was similar in the two groups. Fourteen patients had duration of dysphagia of 1 to 5 years (median: 3 years), and 16 patients had duration of dysphagia of 10 to 60 years (median: 16 years).

The control group consisted of 22 subjects, 5 men and 17 women, also divided into a younger group aged 33 to 58 years, median 42 years (mean: $44 \pm 9$ years, $n=15$ ) and an older group aged 61 to 73 years, median 66 years (mean: $66 \pm 4$ years, $n=7$ ). The controls were submitted to esophageal manometry during the investigation of gastroesophageal reflux disease, and had normal esophageal endoscopic and radiologic examinations. The protocol of manometric examination was approved by the Human Research Committee of the University Hospital of Ribeirão Preto, SP, Brazil.

The manometric examination was performed with a round eight-lumen polyvinyl catheter with an outer diameter of $4.5 \mathrm{~mm}$ and an inner diameter of $0.8 \mathrm{~mm}$ (Arndorfer Specialities, Inc, Greendale, Wisconsin, USA). The four proximal lateral openings of the catheter were spaced $5 \mathrm{~cm}$ apart at $90^{\circ}$ angles. They were connected to external pressure transducers (pvb Medizintechnik $\mathrm{Gmb}$ H, Kirchseeon, Germany), which in turn were connected to a PC Polygraph HR (Synectics Medical, Stockholm, Sweden). The manometric signals were stored in a computer. During the manometric recordings, a minimally compliant pneumohydraulic pump (JS Biomedicals, Ventura, CA, USA) perfused distilled water at $0.5 \mathrm{~mL} / \mathrm{min}$ through each lumen.

All individuals were studied in the supine position after $12 \mathrm{~h}$ of fasting. The catheter was introduced through the nose. For the study of esophageal contractions, the catheter was positioned with the proximal opening located $2 \mathrm{~cm}$ below the upper esophageal sphincter (UES) and the other openings located at 7,12 and $17 \mathrm{~cm}$ from the UES. Five swallows of a $5-\mathrm{mL}$ bolus of water were performed, with an interval of at least 20 seconds between successive swallows.

Using the computer Polygram Upper GI software version 6.4 (Gastrosoft, Stockholm, Sweden) we measured the amplitude and duration of the contractions and the time interval between the upstroke of the contractions measured $5 \mathrm{~cm}$ apart. Contractions separated less than 1 second at recording sites $5 \mathrm{~cm}$ apart were considered to be simultaneous. Non-conducted contractions occur when there is no contraction propagation between two points of the esophageal body.

Data were analyzed statistically by analysis of variance, by the Tukey-Kramer multiple comparisons test, the unpaired $t$ test, and the Fisher exact test. Differences were considered to be significant when $P<0.05$. The results are reported as mean \pm SEM unless otherwise indicated.

\section{RESULTS}

Comparison between patients with Chagas' disease and controls revealed a lower amplitude of contractions in patients at 7,12 and $17 \mathrm{~cm}$ from the UES $(P<0.01$, Table 1$)$. Patients with Chagas' disease had fewer peristaltic, more simultaneous and more non-conducted contractions than controls $(P<0.05$, Figure 1). There were no differences between patients and controls in duration of contraction or velocity of peristaltic contractions $(P>0.05)$.

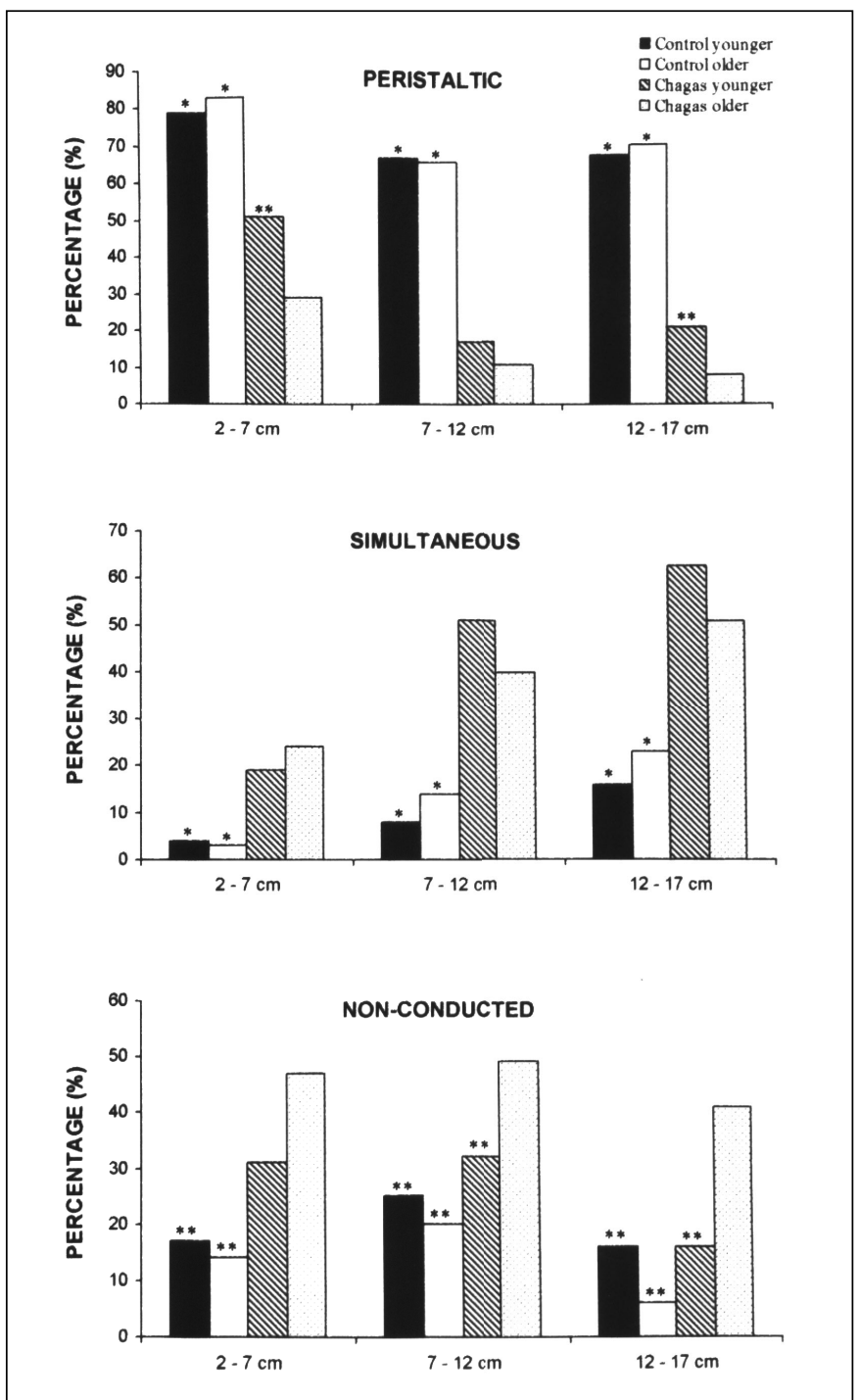

FIGURE 1 - Percentage of esophageal peristaltic, simultaneous and nonconducted contractions measured from 2 to $7 \mathrm{~cm}$, from 7 to $12 \mathrm{~cm}$ and from 12 to $17 \mathrm{~cm}$ below the UES after swallows of a $5 \mathrm{~mL}$ bolus of water. ${ }^{*} P<0.05$ vs younger and older patients with Chagas' disease; ${ }^{* *} P<0.05$ vs older patients with Chagas' disease 
Older patients with Chagas' disease had lower amplitude of contractions at $17 \mathrm{~cm}$ from the UES $(30.8 \pm 4.3 \mathrm{~mm} \mathrm{Hg})$ than younger patients $(51.9 \pm 8.6 \mathrm{~mm} \mathrm{Hg}, P<0.05$, Figure 2$)$, and had more non-conducted (41\%) and fewer peristaltic $(8 \%)$ contractions from 12 to $17 \mathrm{~cm}$ than younger patients (non-conducted: $16 \%$, peristaltic: $21 \%, P<0.05$, Figure 1). There were no differences between younger and older patients in duration or velocity of contractions $(P>0.05$, Table 1$)$.

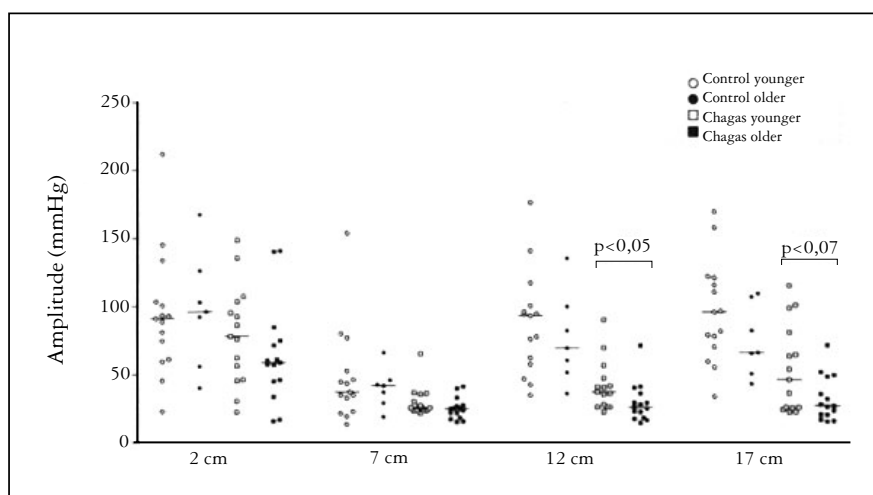

FIGURE 2 - Amplitude of esophageal contractions at 2, 7, 12 and $17 \mathrm{~cm}$ from the UES after swallows of a $5 \mathrm{~mL}$ bolus of water. The amplitude was lower in patients than in controls at 7 , 12 and $17 \mathrm{~cm}$ from the UES, and lower in older Chagas disease patients than in younger patients at 17 from the UES. The horizontal bars represent the medians

TABLE 1 - Amplitude, duration and velocity of esophageal contractions after wet swallows in younger $(n=15)$ and older $(n=15)$ patients with Chagas' disease, and younger $(\mathrm{n}=15)$ and older $(\mathrm{n}=7)$ control subjects, measured at 2,7,12 and $17 \mathrm{~cm}$ from the upper esophageal sphincter $($ mean \pm SEM)

\begin{tabular}{|c|c|c|c|c|}
\hline & \multicolumn{4}{|c|}{ Amplitude $(\mathrm{mm} \mathrm{Hg})$} \\
\hline & $2 \mathrm{~cm}$ & $7 \mathrm{~cm}$ & $12 \mathrm{~cm}$ & $17 \mathrm{~cm}$ \\
\hline \multicolumn{5}{|l|}{ Controls } \\
\hline Younger & $93.5 \pm 11.7$ & $46.3 \pm 9.1^{\mathrm{a}}$ & $85.7 \pm 9.8^{\mathrm{a}}$ & $94.3 \pm 10.0^{2}$ \\
\hline Older & $96.8 \pm 16.1$ & $38.8 \pm 5.6^{\mathrm{b}}$ & $74.6 \pm 12.6^{a}$ & $72.8 \pm 9.8^{\mathrm{b}}$ \\
\hline \multicolumn{5}{|c|}{ Chagas' disease } \\
\hline Younger & $78.3 \pm 9.4$ & $28.4 \pm 2.9$ & $39.7 \pm 4.9^{c}$ & $51.9 \pm 8.6^{\mathrm{d}}$ \\
\hline \multirow[t]{3}{*}{ Older } & $63.3 \pm 9.5$ & $23.5 \pm 2.3$ & $27.3 \pm 3.8$ & $30.8 \pm 4.3$ \\
\hline & \multicolumn{4}{|c|}{ Duration (seconds) } \\
\hline & $2 \mathrm{~cm}$ & $7 \mathrm{~cm}$ & $12 \mathrm{~cm}$ & $17 \mathrm{~cm}$ \\
\hline \multicolumn{5}{|l|}{ Controls } \\
\hline Younger & $2.7 \pm 0.2$ & $3.1 \pm 0.2$ & $3.8 \pm 0.2$ & $4.5 \pm 0.3$ \\
\hline Older & $2.1 \pm 0.3$ & $2.9 \pm 0.3$ & $3.3 \pm 0.3$ & $3.5 \pm 0.3$ \\
\hline \multicolumn{5}{|c|}{ Chagas' disease } \\
\hline Younger & $2.7 \pm 0.3$ & $3.7 \pm 0.4$ & $3.8 \pm 0.4$ & $4.2 \pm 0.4$ \\
\hline \multirow[t]{3}{*}{ Older } & $2.4 \pm 0.2$ & $3.4 \pm 0.2$ & $3.4 \pm 0.3$ & $3.6 \pm 0.2$ \\
\hline & \multicolumn{4}{|c|}{ Velocity $(\mathrm{cm} / \mathrm{s})$} \\
\hline & $2 \rightarrow 7 \mathrm{~cm}$ & & $7 \rightarrow 12 \mathrm{~cm}$ & $12 \rightarrow 17 \mathrm{~cm}$ \\
\hline \multicolumn{5}{|l|}{ Controls } \\
\hline Younger & $1.9 \pm 0.2$ & & $2.9 \pm 0.2$ & $3.1 \pm 0.2$ \\
\hline Older & $1.7 \pm 0.2$ & & $2.9 \pm 0.1$ & $3.2 \pm 0.3$ \\
\hline \multicolumn{5}{|c|}{ Chagas' disease } \\
\hline Younger & $1.8 \pm 0.3$ & & $2.3 \pm 0.3$ & $2.6 \pm 0.4$ \\
\hline Older & $1.8 \pm 0.2$ & & $2.2 \pm 0.2$ & $3.5 \pm 0.3$ \\
\hline
\end{tabular}

$P<0.01$ vs Chagas' disease

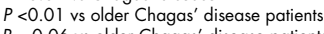

C $P=0.06$ vs older Chagas' disease patients
d $P<0.05$ vs older Chagas' disease patients
There was no difference between younger and older controls $(P>0.05)$. There were also no differences between patients with duration of dysphagia of less than 6 years $(n=14)$ and patients with duration of dysphagia of more than 10 years $(\mathrm{n}=16)(P>0.05$, Table 2$)$.

TABLE 2 - Results of distal esophageal manometric examination in patients with a duration of dysphagia of 1 to 5 years (median 3 years, $\mathrm{n}=14)$, and in patients with a duration of dysphagia of 10 to 60 years (median 16 years, $n=16)($ mean \pm SEM)

\begin{tabular}{lcc}
\hline & \multicolumn{2}{c}{ Duration of dysphagia } \\
\cline { 2 - 3 } Contraction & 1 to 5 years & 10 to 60 years \\
\hline Amplitude (mm Hg) & $39.1 \pm 8.0$ & $31.9 \pm 4.8$ \\
Duration (seconds) & $4.1 \pm 0.4$ & $3.5 \pm 0.3$ \\
Simultaneous (\%) & 50.0 & 61.7 \\
Peristaltic (\%) & 16.0 & 10.0 \\
Non-conducted (\%) & 34.0 & 28.3 \\
\hline$P>0.05$
\end{tabular}

$P>0.05$

\section{DISCUSSION}

The lower amplitude of contractions, and the larger number of simultaneous and non-conducted contractions found here in patients with Chagas' disease compared to controls are in agreement with previous reports ${ }^{(1,3,4,5,22)}$. Older patients with Chagas' disease with clinical and radiologic examination similar to that of younger patients had a lower amplitude of contractions and more non-conducted contractions in the distal esophagus than younger patients, showing a decrease in the capacity of contractions in the distal esophagus of older patients compared to younger patients.

The differences between younger and older patients with Chagas' disease may be the result of the progression of the disease along the lifetime. However, only a small number of patients have this evolution and most of them remain stable for a long time ${ }^{(1,14,20)}$ before reaching advanced ages.

The human myenteric esophageal neurons decrease in number in older subjects without esophageal diseases ${ }^{(8,16,19,27)}$, an event which is accompanied by an increase in neuron size ${ }^{(19)}$. These alterations in neurons may explain the significant decrease in esophageal pressure amplitude with aging reported mainly in the eighth and ninth decades ${ }^{(6,13,24)}$ and aperistalsis in older subjects $^{(6,11,21,23)}$. The enteric sensory neurons are particularly susceptible to neurodegeneration with age ${ }^{(27)}$. They exhibit neurodegeneration to a greater extent than other phenotypes, serotonergic interneurons or nitrergic inhibitory motor neurons ${ }^{(27)}$. The nitrergic inhibitory motor neurons ${ }^{(3)}$, and probably sensory neurons ${ }^{(9)}$, are affected by Chagas' disease. When a patient has megaesophagus the myenteric plexus is almost completely absent, but in patient with no dilatation the myenteric plexus destruction is only partial ${ }^{(15)}$.

Deterioration of esophageal motility of patients over 60 years of age compared with patients under 60 years may not be enough to cause clinical or radiologic differences between them. According to our radiologic classification into grades I to $\mathrm{IV}^{(20)}$, they were grade I, corresponding to the less severe stage of the disease. Even asymptomatic patients ${ }^{(4)}$ or patients with normal radiologic examination ${ }^{(1)}$ may have alterations in esophageal motility. The severity of esophageal alterations in 
Chagas' disease ${ }^{(15,16)}$ or in idiopathic achalasia ${ }^{(12)}$ is related to the intensity of denervation.

The possibility of progression of the disease with the aging process may influence the late evolution of the disease. We have seen patients with Chagas' disease who had worsening of dysphagia after years of living with this complaint, or even beginning to have dysphagia after the fifth or sixth decades, although they had an epidemiologic history of contamination during childhood. This may affect the outcome of patients treated by pneumatic dilatation or esophagomyotomy. After treatment, some patients experience an improved ability to have regular meals but after some time their symptoms become worse. This situation is observed both in Chagas' disease ${ }^{(10)}$ and in idiopathic achalasia ${ }^{(17,25,26,28)}$. Although aging may not be a complete explanation, and not in all cases of worsening of symptoms some time after treatment, it may have some participation.

It was not surprising for us that patients had not received previous treatment for the complaint. They were used to having dysphagia for a long time, and had adapted by eating slowly soft food, drinking water during meals and performing some maneuvers after swallowing, such as arching the neck or shoulders, raising the arms or performing the Valsalva maneuver. Living with dysphagia for years is a consequence of the low social class of these patients and the problems to obtain medical care in the areas where Chagas' disease is endemic.
In a previous study we found that patients with Chagas' disease and normal subjects showed the same quantitative aspects of esophageal contractions when 5 swallows or 10 swallows were analyzed ${ }^{(2)} \mathrm{We}$ take the UES as reference for the catheter position because we want to be sure to register the esophageal striated muscle contractions $(2 \mathrm{~cm})$ and the esophageal smooth muscle contractions $(17 \mathrm{~cm})$. Our control group had the possibility of having gastroesophageal reflux disease or functional heartburn. Only a substantial minority of patients with symptoms of reflux and normal endoscopic and radiologic esophageal examination have minor alterations of esophageal motility ${ }^{(14)}$. None of the volunteers had esophageal alterations of peristalsis or reported dysphagia.

Some studies found that the incidence of idiopathic achalasia increases with age, with a more intense increase after the sixties ${ }^{(18)}$, suggesting that also in the idiopathic form of achalasia the aging process may influence the outcome of the disease. Esophageal motility alterations with advancing age may be associated with coexisting disease $\mathrm{e}^{(7)}$.

In conclusion, we found more intense alterations of esophageal motility in older patients with Chagas' disease than in younger patients, all with similar radiological and clinical manifestations, a fact suggesting that the aging process may cause further alterations in esophageal motility in patients with established esophageal disease. The difference was not the consequence of the duration of dysphagia.

Dantas RO, Aprile LRO. Comparação em duas faixas etárias das alterações motoras do esôfago conseqüentes à doença de Chagas. Arq Gastroenterol. 2006;43(4): 196-200.

RESUMO - Racional - Doença de Chagas e o processo do envelhecimento causam perda de neurônios do plexo mientérico do esôfago. Objetivo - Avaliar em duas faixas etárias as possíveis alterações da motilidade do esôfago em pacientes com doença de Chagas. A hipótese é de que o envelhecimento pode provocar aumento na intensidade das alterações motoras do esôfago conseqüentes à doença de Chagas. Pacientes $\boldsymbol{e}$ Método - Estudou-se a motilidade do esôfago em 30 pacientes com doença de Chagas e disfagia, com retenção do meio de contraste no exame radiológico do esôfago, com diâmetro do órgão dentro dos limites normais. Quinze tinham de 34 a 59 anos (mediana: 51 anos) e 15 tinham de 61 a 77 anos (mediana: 66 anos). Como grupo controle, estudaram-se 15 pessoas com idades entre 33 e 58 anos (mediana: 42 anos) e 7 pessoas com idades entre 61 e 73 anos (mediana: 66 anos). As contrações esofágicas foram medidas pelo método manométrico com perfusão contínua, após cinco deglutições de $5 \mathrm{~mL}$ de água, a 2, 7, 12 e $17 \mathrm{~cm}$ distal ao esfíncter superior do esôfago. Resultados - Pacientes com doença de Chagas tiveram menor amplitude das contrações, menor proporção de contrações peristálticas, maior proporção de contrações simultâneas e maior proporção de contrações não propagadas do que os controles. Os pacientes com doença de Chagas e mais idade tiveram menor amplitude das contrações em esôfago distal (média \pm EP: 30,8 $\pm 4,3 \mathrm{~mm} \mathrm{Hg}$ ) do que os pacientes com menos idade $(51,9 \pm 8,6 \mathrm{~mm} \mathrm{Hg})$. Entre 12 e $17 \mathrm{~cm}$ do esfíncter superior do esôfago os pacientes de mais idade tiveram mais contrações não propagadas $(41 \%)$ e menos contrações peristálticas $(8 \%)$ do que os pacientes com menos idade (não propagadas: 16\% peristálticas 21\%). Conclusão - Pacientes com doença de Chagas mais idosos, com clínica e exame radiológico do esôfago similar ao de pacientes mais jovens, têm alterações motoras do esôfago que sugerem que o envelhecimento pode provocar comprometimento adicional à motilidade do esôfago.

DESCRITORES - Esôfago. Doença de Chagas. Envelhecimento. Acalásia. Motilidade do esôfago. 


\section{REFERENCES}

1. Dantas RO. Dysphagia in patients with Chagas' disease. Dysphagia. 1998;13:53-7.

. Dantas RO. Effect of successive swallows on oesophageal motility of normal volunteers, patients with Chagas' disease and patients with idiopathic achalasia. Neurogastroentero Motil. 2003:15:57-62.

3. Dantas RO. Comparação entre acalásia idiopática e acalásia conseqüente à doença de Chagas. Arq Gastroenterol. 2003;40:126-30.

4. Dantas RO, Deghaide NHS, Donadi EA. Esophageal manometric and radiologic finding in asymptomatic subjects with Chagas' disease. J Clin Gastroenterol. 1999;28:245-

5. Dantas RO, Deghaide NHS, Donadi EA. Esophageal motility of patients with Chagas' disease and idiopathic achalasia. Dig Dis Sci. 2001;46:1200-6.

6. Deprez H, Fiasse R. Healing of severe esophagitis improves esophageal peristaltic dysfunction. Dig Dis Sci. 1999;44:125-31.

7. DeVault KR. Presbyesophagus: a reappraisal. Curr Gastroenterol Rep. 2002;4:193-9.

8. Eckardt VF, LeCompte PM. Esophageal ganglia and smooth muscle in the elderly. Am J Dig Dis. 1978;23:443-8.

9. Ejima FH, Dantas RO, Simões MV, Marin-Neto JA, Meneghelli UG. Intraesophagea balloon distension test in Chagas' disease patients with noncardiac chest pain. Dig Dis Sci. 1998;43:2567-71

10. Ferraz AA, Nobrega Jr BG, Mathias CA, Bacelar TS, Lima FE, Ferraz EM. Late results on the surgical treatment of chagasic megaesophagus with the Thal-Hatafuku procedure. J Am Coll Surg. 2001;193:493-8.

11. Ferriolli E, Dantas RO, Oliveira RB, Braga FJHN. The influence of aging on oesophagea motility after ingestion of liquids with different viscosities. Eur J Gastroenterol Hepatol. 1996;8:793-8.

12. Goldblum JR, Rice TW, Richter JE. Histopathologic features in esophagomyotomy specimens from patients with achalasia. Gastroenterology. 1996;111:648-54.

13. Hollis JB, Castell DO. Esophageal function in elderly men: a new look at presbyesophagus. Ann Intern Med. 1974;91:897-904.

14. Kahrilas PJ, Dodds WJ, Hogan WJ, Kern M, Arndorfer RC, Reece A. Esophagea peristaltic dysfunction in peptic esophagitis. Gastroenterology. 1986;91:897-904

15. Köberle F. Enteromegaly and cardiomegaly in Chagas' disease. Gut. 1963;4:399-405.
16. Köberle F. Chagas' disease and Chagas' syndrome: the pathology of American Trypanosomiasis. Adv Parasitol. 1968;6:63-116.

17. Massey BT. Management of idiopathic achalasia: short-term and long-term outcomes. Curr Gastroenterol Rep. 2000;2:196-200.

18. Mayberry JF, Atkinson M. Variations of the prevalence of achalasia in Great Britain and Ireland: an epidemiological study based on hospital admissions. Q J Med. 1987;62:67-

19. Meciano-Filho J, Carvalho VC, Souza RR. Nerve cell loss in the myenteric plexus of the human esophagus in relation to age: a preliminary investigation. Gerontology. 1995;41:18-21.

20. Meneghelli UG, Peria FM, Darezzo FMR, Almeida FH, Rodrigues CM, Aprile LRO, Dantas RO. Clinical, radiographic and manometric evolution of esophageal involvement by Chagas' disease. Dysphagia. 2005;20:40-5.

21. Meshkinpour H, Haghighat P, Dutton C. Clinical spectrum of esophageal aperistalsis in the elderly. Am J Gastroenterol. 1994;89:1480-3.

22. Oliveira RB, Troncon LEA, Dantas RO, Meneghelli UG. Gastrointestinal manifestations of Chagas' disease. Am J Gastroenterol. 1998;93:884-9.

23. Ribeiro AC, Klingler PJ, Hinder RA, DeVault KR. Esophageal manometry: a comparison of findings in younger and older patients. Am J Gatroenterol. 1998;93:706-10.

24. Soergel KH, Zboralske FF, Amberg JR. Presbyesophagus, esophageal motility in nonagenarians. J Clin Invest. 1964;45:1472-9.

25. Vaezi MF, Richter JE. Diagnosis and management of achalasia. Am J Gastroenterol. 1999;94:3406-12.

26. Vela MF, Khandwala F, Wachsberger D, Rice TW, Richter JE. Current treatments for achalasia are not curative: the long-term effect of pneumatic dilatation and Heller myotomy [abstract]. Gastroenterology. 2004;126:A27.

27. Wade PR, Cowen T. Neurodegeneration: a key factor in the aging gut. Neurogastroenterol Motil. 2004;16(Suppl 1):19-23.

28. West RL, Hirsch DP, Bartelsmen JF, Borst J, Ferwerda G, Tytgat GN, Boeckxstaens GE. Long term results of pneumatic dilatation in achalasia followed for more than 5 years. Am J Gastroenterol. 2002;97:1346-51.

Recebido em 13/9/2005. Aprovado em 8/3/2006. 